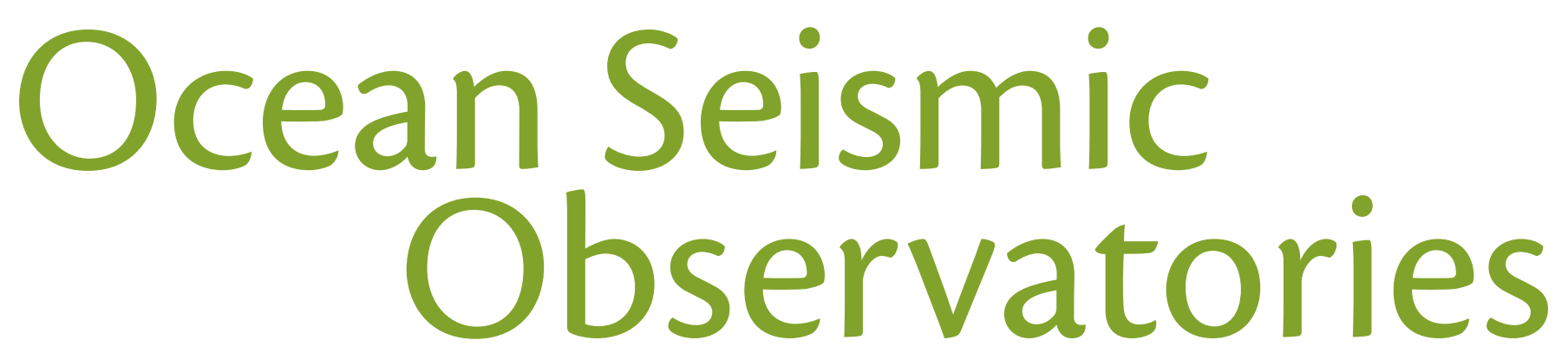

BY KIYOSHI SUYEHIRO, JEAN-PAUL MONTAGNER, RALPH A. STEPHEN,

EIICHIRO ARAKI, TOSHIHIKO KANAZAWA, JOHN ORCUTT,

BARBARA ROMANOWICZ, SELWYN SACKS, AND MASANAO SHINOHARA

Global seismic observations are essential for understanding earthquake mechanisms and for building a threedimensional picture of Earth's internal structure. Seismic waves generated by large earthquakes, in particular, travel through Earth's deep interior and can be recorded at stations around the globe. This seismological information, together with other geophysical and geological data, can be used to infer Earth's geologic history and also to study its present-day dynamics, such as mantle convection and plate motions.

Kiyoshi Suyehiro (suyehiro@jamstec.go.jp) is Executive Director, Japan Agency for Marine-Earth Science and Technology (JAMSTEC), Yokosuka, Kanagawa, Japan. Jean-Paul Montagner is Professor of Geophysics, Institut de Physique du Globe, Paris, France. Ralph

A. Stephen is Senior Scientist, Woods Hole Oceanographic Institution, Woods Hole, MA, USA. Eiichiro Araki is Researcher, Institute for Research on Earth Evolution (IFREE),

JAMSTEC, Yokosuka, Kanagawa, Japan. Toshihiko Kanazawa is Professor, Earthquake Research Institute, University of Tokyo, Tokyo, Japan. John Orcutt is Associate Vice Chancellor for Research, University of California, San Diego, CA, USA. Barbara Romanowicz is Professor of Geophysics and Director, Seismological Laboratory, University of California, Berkeley, CA, USA. Selwyn Sacks is Staff Member, Department of Terrestrial Magnetism, Carnegie Institution of Washington, Washington, D.C., USA. Masanao Shinohara is Associate Professor, Earthquake Research Institute, University of Tokyo, Tokyo, Japan. 


\section{THE INTERNATIONAL}

\section{OCEAN NETWORK}

The international scientific community recognizes the importance of estab-

lishing long-term ocean observatories through international coordination and cooperation. The International Ocean

Network (ION) was formed in 1993 to:

- foster synergies among different disciplines requiring long-term observations in the ocean,

- facilitate cooperation in the development of critical elements of observing systems,

- encourage standards and best practices for shared maintenance of observatories,

- develop common plans for the use of international resources,

- encourage the timely exchange of data, and

- coordinate location plans (more information available at www.deos. org/ion).

A multidisciplinary approach and multiple-purpose investigations are considered important factors to bear in mind when constructing ocean-network nodes.

Implementing an ocean network is a very difficult task: hostile environmental conditions prevail at the bottom of the ocean; it is difficult to maintain stable observations for extended time periods; timely data retrieval is critical; and power supplies must be maintained often for several years at a time. Scientific community workshops addressing these issues have defined a three-phase approach to installing ocean seismic observatories (Purdy and Dziewonski, 1988; Montagner and Lancelot, 1995). In Phase 1 (now complete), pilot experiments addressed the fundamental problems of sensor coupling in holes, noise, devising solutions for power, data retrieval, and reliability on multiple-year timescales.

In Phase 2, a small number of prototype observatories will be installed, which will immediately contribute data to the seismological community. Phase 3 is the full implementation of the global network.

The earliest attempts to install ocean borehole seismographs in Deep Sea Drilling Project (DSDP) holes were made by groups in Britain and the United States between 1976 and 1982, before the era of digital broadband sensors. Digital and broadband stations were developed later, during the Ocean Drilling Program (ODP). Several groups in Japan, France, and the United States began preliminary experiments with the goal of installing permanent seismic stations in ODP boreholes. These experiments included the Japanese test at ODP Hole 794D in the Sea of Japan in 1989 (Kanazawa et al., 1992; Suyehiro et al., 1992) and the French SISMOBS seismometer test at Hole 396B near the Mid-Atlantic Ridge in 1992 (Montagner et al., 1994; Beauduin et al., 1996). The Japan Sea experiment recorded teleseismic (distant) events and obtained broadband seismic noise spectra verifying that ocean boreholes require installation of extremely sensitive sensors (Kanazawa et al., 1992).

In May 1992, French scientists successfully conducted the pilot experiment OFM/SISMOBS in the North Atlantic

Ocean. Two sets of very sensitive broadband seismometers were installed inside DSDP Hole $396 \mathrm{~B}\left(23^{\circ} \mathrm{N}, 43.3^{\circ} \mathrm{W}\right)$ and another was buried beside it. These instruments operated for more than one week and were then recovered (Montagner et al., 1994). The experiment required the simultaneous use of the oceanographic vessel Nadir, the submersible Nautile, and the reentry logging system Nadia. Scientists observed that the amplitude of noise decreased systematically and rapidly for the borehole sensor at long periods (greater than 50 seconds), which was not the case for the seafloorburied sensor. Based on these results, it was determined that an experiment of longer duration was desirable.

A more comprehensive test was the Ocean Seismic Network Pilot Experiment (OSNPE) in 1998, which compared seafloor, shallow-buried, and borehole broadband seismometers at the same location (ODP Site 843, Southwest of Oahu, Hawaii) for a duration of four months (Collins et al., 2001; Stephen et al., 2003; Sutherland et al., 2004). All three systems were exposed simultaneously to the same ambient noise environment and acquired data for the same earthquake events. The most meaningful test of the three configurations was a comparison of earthquake event detectability (Sutherland et al., 2004). The test indicated that although burying a broadband sensor gave considerable improvement over a seafloor sensor at low frequencies, the best detector across the spectrum for teleseismic $\mathrm{P}$, teleseismic $\mathrm{S}$, and Rayleigh and Love waves was the borehole sensor. In fact, the borehole seismometer outperformed the Global Seismic Network (GSN) station (KIP) on Oahu in all cases (Stephen et al., 2003). The borehole sensor was estimated to be able to detect teleseismic $\mathrm{P}$-waves from earthquakes down to $\mathrm{M}$ (magnitude) 4.3 and to detect teleseismic S-waves and surface waves from earthquakes down to M 4.0. 


\section{RECENT DEVELOPMENTS AND FINDINGS}

Table 1 summarizes eight sites that were identified for prototype stations by ION during ODP (1998-2003). All of the sites drilled are thoroughly documented in the ODP literature.

Japanese scientists, under the Ocean Hemisphere Network Project (19962001), instrumented two boreholes in the Japan Trench (JT-1 and JT-2), one in the Philippine Sea (WP-1), and one in the Northwest Pacific (WP-2) (Figure 1a). These four sites use autonomous, battery-powered recording and data packages that are retrieved by remotely operated vehicles (ROVs) (Shinohara et al., 2002; Suyehiro et al., 2002) (Figure 1b). There are cables near JT-1, JT-2, and WP-1 that could be used for power and data telemetry in future developments at these sites.

To understand the consequences of plate subduction, data from land stations are insufficient simply because they can- not cover the fault zone. For example, across northern Japan, land covers only a portion of the whole plate subduction zone. Furthermore, large interplate earthquake slips mainly occur seaward of the coastline. Therefore, it is imperative to have permanent offshore stations to monitor seismicity and crustal deformation (Sacks et al., 2000). For the JT sites, tiltmeters and strainmeters also were included in the installation. The installed tiltmeter measures the tilt of the ground to nanoradians ( 1 nanoradian is $1 \mathrm{~mm}$ tilt over $1000 \mathrm{~km}$ ). The strainmeter measures down to picostrains (rocks fracture at $10^{-4}-10^{-5}$ strain).

Figure 2 summarizes ambient noise spectra from all of the broadband borehole seismic installations that have been instrumented to date (Shinohara et al., in press). The seafloor borehole spectra fall within the high- and low-noise models based on land stations except at very low frequencies on the horizontal channels of two stations. Ambient noise at seafloor stations is not, in general, greater than at continental or island stations as previously suspected. At some frequencies, some of the seafloor borehole stations are as quiet as the quietest land stations. Figure 3 schematically shows how borehole sensors can outperform seafloor sensors.

Building a network in the oceans and accumulating natural earthquake data takes persistent effort and time. Preliminary results indicate that the scientific reward will accelerate with increasing network density. For example, data from WP- 1 in the middle of the Philippine Sea Plate were used to look at mantle discontinuities immediately below that location (Suetsugu et al., 2005). The observed velocity jumps are created by mineral phase changes caused by temperature and pressure conditions. Results suggest lower-than-normal temperature at the boundary between the upper and lower mantle at around 660-km depth, caused by the cold subducted Pacific Plate that is

Table 1. Summary of holes proposed for ION prototype stations 1998-2003

\begin{tabular}{|c|c|c|c|}
\hline Area & $\begin{array}{l}\text { Data } \\
\text { Recovery }\end{array}$ & $\begin{array}{c}\text { Drilling Program } \\
\text { Leg/Site }\end{array}$ & Instrumented \\
\hline \multicolumn{4}{|c|}{ Active Processes } \\
\hline Japan Trench (OHP-JT-1, JT-2)—-subduction dynamics & Ship & $186 / 1150,1151$ & Yes (two sites) \\
\hline \multicolumn{4}{|c|}{ Global Seismology } \\
\hline Philippine Sea (OHP-WP-1)_fate of subducted plate & Ship & $195 / 1201$ & Yes \\
\hline Northwest Pacific (OHP-WP-2)_global coverage & Ship & $191 / 1179$ & Yes \\
\hline Northeast Pacific (OSN-H2O)_global coverage & Cable & $200 / 1224$ & No \\
\hline Center of Nazca Plate (OSN)_-global coverage & Ship & No & No \\
\hline Eastern Equatorial Pacific (OSN)_-global coverage & Ship & $203 / 1243$ & No \\
\hline Ninetyeast Ridge (OFM-NERO)_-global coverage & Ship & $179 / 1107$ & No \\
\hline \multicolumn{4}{|c|}{ Existing Hole from Deep Sea Drilling Project } \\
\hline Middle Atlantic (OFM-SISMOBS, OFP)_ _ global coverage & Ship & $46 / 396 B$ & Formerly \\
\hline
\end{tabular}




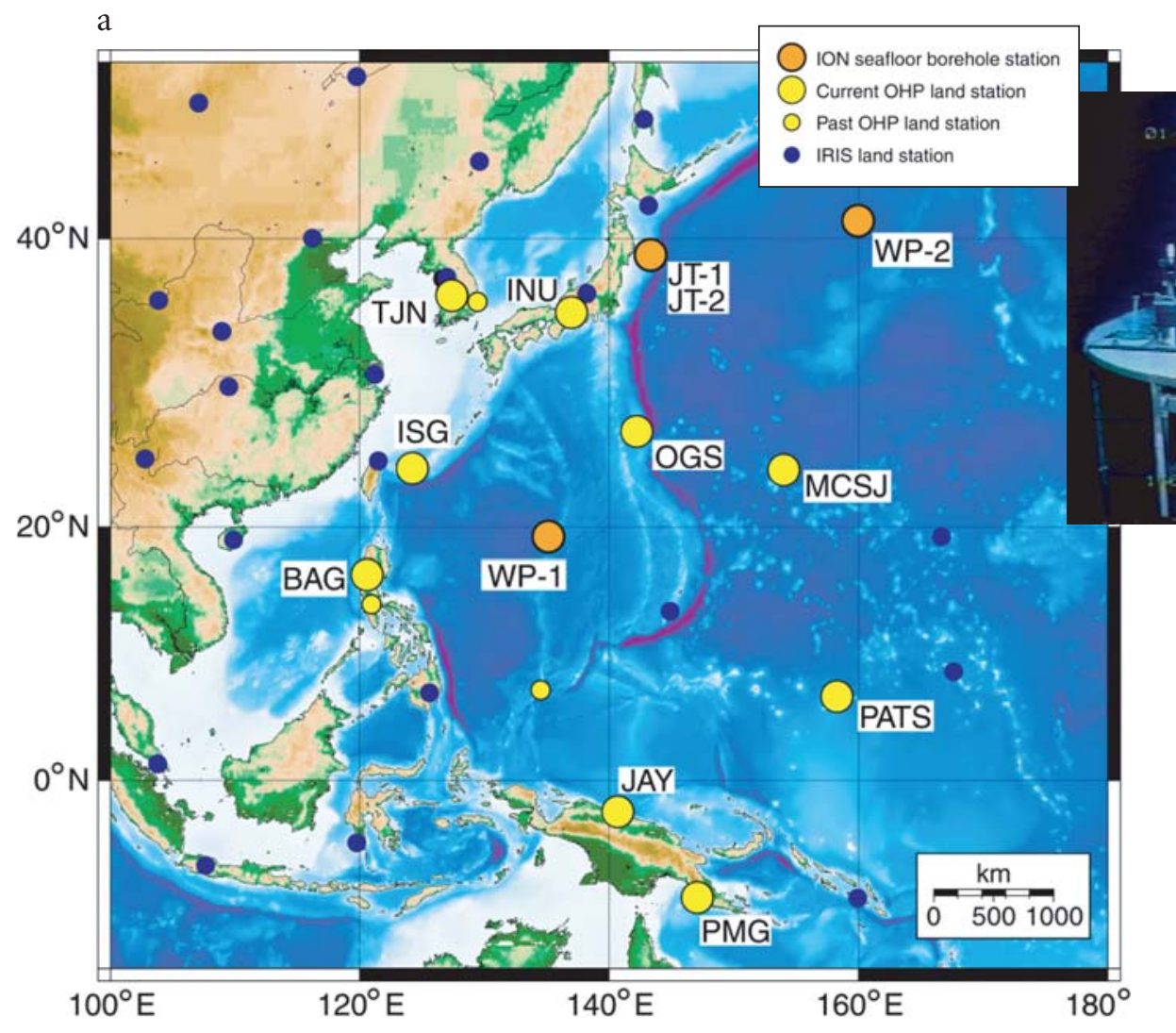

Figure 1. (a) Location of Ocean Hemisphere Project (OHP) observatories in the western Pacific. Stations are spaced at about $1000-\mathrm{km}$ apart. Orange circles are the OHP borehole stations as part of the ION network, from which long-term data have been obtained. IRIS is the Incorporated Research Institutions for Seismology (http://www. iris.edu). (b) Observation platform at the WP-2 borehole observatory viewed from the JAMSTEC remotely operated vehicle (ROV) "Kaiko," which is one of the ROVs that maintain the Japanese borehole stations.
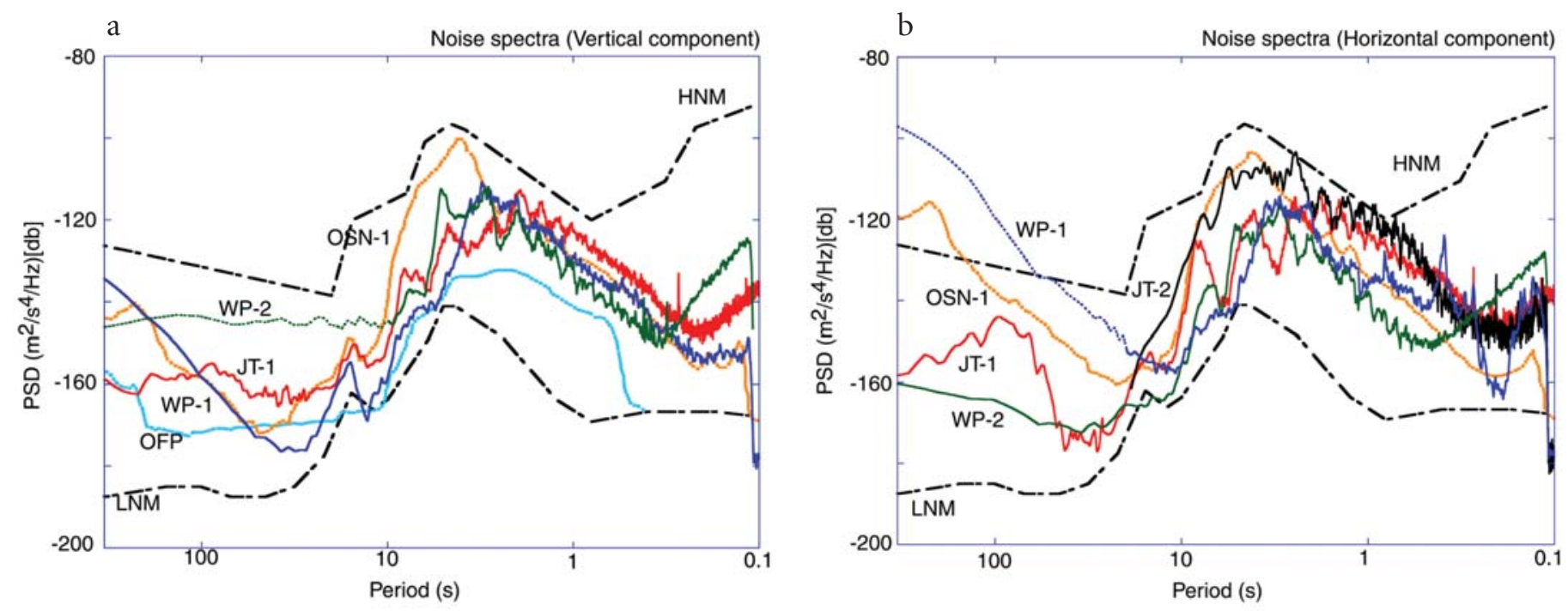

Figure 2. Comparison of ambient seismic noise among the borehole stations that have been instrumented to date. (a) Vertical component. (b) Horizontal component. See Table 1 for most station identifications; OSN-1 is the OSNPE. HNM and LNM are the high-and low-noise models accepted by the seismological community (Peterson, 1993). Results show that seafloor stations are not, in general, noisier than continental or island stations as previously suspected. There is no horizontal record for OFP. Because each installation differs in many aspects, it is important to recognize the specific environmental conditions of each. 


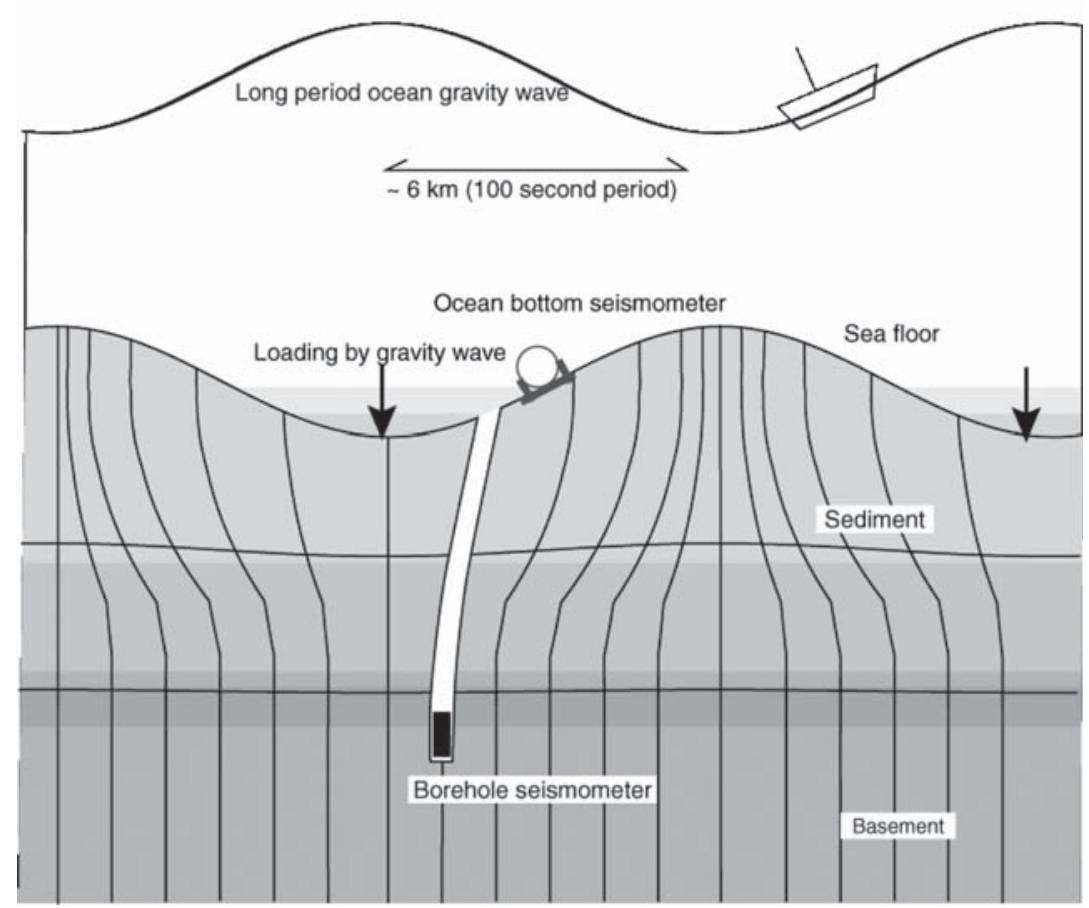

Figure 3. Schematic view of how borehole sensors can out-perform seafloor sensors. Boreholes are significantly quieter than ocean-floor installations (even buried ones) at body wave frequencies, because they avoid signal-generated noise from reverberations in the soft sediment layers. When properly installed, boreholes are also significantly quieter at low frequencies (surface wave and free oscillation band) because the sensors are less affected by tilts due to ocean currents (Araki et al., 2004).

unable to penetrate the lower mantle.

Data from WP-2 show that M 4.5 earthquakes can be clearly recorded, similar to the OSNPE result. There are modes (phases) of $\mathrm{P}$ and $\mathrm{S}$ waves that travel in the lithosphere for long distances and WP-2 is an optimal position to record seismic waves for pure oceanic paths. Data showed that such $\mathrm{S}$ phases persist for 2,500 km (Araki et al., 2003). Explaining such arrivals requires uppermantle velocities that are several percent faster than standard models. Evidence from recorded surface waves also indicates meaningful discrepancies from the model. These results are strong indicators that mantle structure beneath the oceans is still largely unconstrained. More ocean stations recording more data are needed to reconcile models with observations.

\section{OBSERVING THE EARTH FROM THE OCEANS}

A modest network of high-quality broadband stations in the deep ocean far from any accessible landmasses can go a long way toward addressing many important issues. The current spatial resolving power of global mantle tomographic models is reaching $1000 \mathrm{~km}$ in lateral extent. As resolving power improves, more attention will be given to the details that are critical for understanding the physical and chemical basis of how Earth developed into its presentday configuration.

Figure 4 is an initial attempt to propose a set of sites, which would fill the most important gaps in ocean coverage, not only for seismology but for other oceanographic disciplines as well. Not all sites are equally important for all seismic studies. For example, the mid-Atlantic site (DSDP Site 396B) does not improve the already adequate coverage for surface waves, but provides a valuable geometry for body-wave sampling of both the upper and lower mantle. It will be necessary for specific site proposals to take into account the broad spectrum of scientific problems being addressed and the actual distribution of earthquake sources. It must be noted that all of the proposed sites in Figure 4 also represent gaps for geomagnetic and geodetic observatories and that the possibility of sharing sites is strongly encouraged.

Although data acquisition has occurred over too short a span to yet lead to significant discoveries, the pilot experiments have demonstrated that ocean-floor stations can provide useful data for global seismological investigations. It is the results from these Phase 2 stations that have encouraged global seismologists to extend their networks to the seafloor. The global seismic community is among the strongest supporters of the Integrated Ocean Drilling Program and the Ocean Research Interactive Observatory Networks (ORION), the European Seafloor Observatory Network (ESONET), and the Advanced Real-Time Earth Monitoring Network in the Area (ARENA)/DONET being planned by American, European, and Japanese scientists, respectively.

\section{ACKNOWLEDGEMENTS}

Establishing long-term seismic observatories in ocean boreholes is truly a new venture that involves many experiments and continual technological refinement. So many people around the globe have 


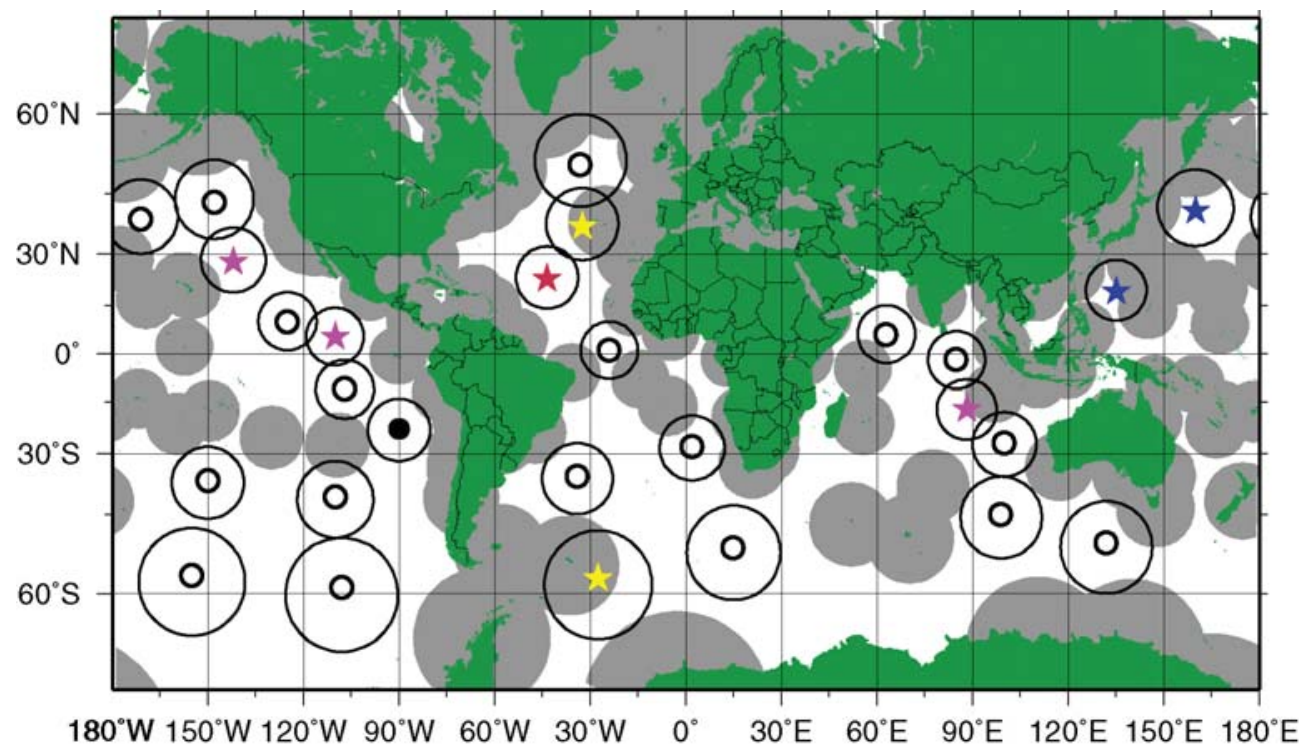

contributed to various nationally and internationally coordinated efforts that it is impossible to list them as individuals. We believe that these endeavors by scientists, engineers, ship officers, crew, program managers, and all those who have had a part will lead to the emergence of a new view of the Earth from the oceans. 屃

\section{REFERENCES}

Araki, E., M. Shinohara, K. Nakahigashi, T. Kanazawa, and K. Suyehiro. 2003. Uppermantle structure beneath the NW Pacific Ocean from using ocean borehole seismic data in the NW Pacific Basin. Gekkan Chikyu [in Japanese] 25:555-560.

Araki, E., M. Shinohara, S. Sacks, A. Linde, T. Kanazawa, H. Shiobara, H. Mikada, and K. Suyehiro. 2004 Improvement of seismic observation in the ocean by use of seafloor boreholes. Bulletin of the Seismological Society of America 94:678-690.

Beauduin, R., J.-P. Montagner, and J.-F. Karczewski. 1996. Time evolution of broadband seismic noise during the French pilot experiment OFM/SISMOBS. Geophysical Research Letters 23:2,995-2,998.

Collins, J.A., F.L. Vernon, J.A. Orcutt, R.A. Stephen, K.R. Peal, F.B. Wooding, F.N. Spiess, and J.A. Hildebrand. 2001. Broadband seismology in the oceans: Lessons from the ocean seismic network pilot experiment. Geophysical Research Letters 28:49-52.

Kanazawa, T., K. Suyehiro, N. Hirata, and M. Shino- hara. 1992. Performance of the ocean broadband downhole seismometer at Site 794. Pp. 1,157-1,171 in Proceedings of the Ocean Drilling Program, Scientific Results, 127/128, K. Tamaki, K. Suyehiro, J. Allan, M. McWilliams, et al., eds. Ocean Drilling Program, College Station, TX.

Montagner J.-P., J.-F. Karczewski, B. Romanowicz, S. Bouaricha, P. Lognonne, G. Roult, E. Stutzmann, J.L. Thirot, J. Brion, B. Dole, D. Fouassier, J.C. Koenig, J. Savary, L. Floury, J. Dupond, A. Echardour, and H. Floc'h. 1994. The French pilot experiment OFM/SISMOBS: Scientific results on noise level and event detection. Physics of the Earth and Planetary Interiors 84:321-336.

Montagner, J.P., and Y. Lancelot, eds. 1995. Multidisciplinary Observatories on the Deep Seafloor. Proceedings of the International Ocean Network, Marseilles, France, 229 pp.

Peterson, J. 1993. Observations and modeling of seismic background noise. USGS Open File Report 93-322. U.S. Geological Survey, Albuquerque, New Mexico.

Purdy, G.M., and A.M. Dziewonski. 1988. Proceedings of a workshop on broad-band downhole seismometers in the deep ocean. Joint Oceanographic Institutions, Inc. and the JOI U.S. Science Advisory Committee, Washington, D.C., 105 pp.

Sacks, I.S., K. Suyehiro, G.D. Acton, et al. 2000. Proceedings of the Ocean Drilling Program, Initial Reports, 186. Ocean Drilling Program, Texas A\&M University, College Station, TX [CD-ROM].

Salisbury, M.H., M. Shinohara, C. Richter et al. 2002. Proceedings of the Ocean Drilling Program, Initial Reports, 195. Ocean Drilling Program, Texas A\&M University, College Station, TX [CD-ROM]. Schofield, O.M.E., and M.K. Tivey. 2005. ORION-
Figure 4. The potential role of ocean borehole sites in global seismic coverage (from Stephen et al., 2003). The grey shaded regions indicate the surface coverage out to $1000 \mathrm{~km}$ from continent and island stations. White spaces are gaps in the land-based coverage. Existing and proposed ocean stations for global coverage are indicated by symbols surrounded by black circles at approximately $1000-\mathrm{km}$ radius. The different symbols show different levels of progress at the ocean sites: red star-the Mid-Atlantic Ridge test site; blue stars-presently operating borehole observatories (the Japan Trench regional sites are not shown); maroon stars-sites at which boreholes have been drilled but have not yet been instrumented; solid and open black circles-high-priority ION sites proposed in 1996 but not yet drilled; and yellow stars-other proposed sites that have not yet been drilled. Many of these seafloor sites share multidisciplinary objectives. Copyright 2003, American Geophysical Union. Reproduced with permission.
Ocean Research Interactive Observatory Networks: A Report of the Workshop Held January 4-8, 2004 San Juan, Puerto Rico, ORION Project Office, Washington, D.C., 140 pp. [Online] Available at: http://www.orionocean.org/documents/default. html [last accessed September 20, 2006].

Shinohara, M., E. Araki, T. Kanazawa, K. Suyehiro, M. Mochizuki, T. Yamada, K. Nakahigashi, Y. Kaiho, and Y. Fukao. In press. Deep-sea borehole seismological observatories in the western Pacific: Temporal variation of seismic noise level and event detection. Annales Geophysicae.

Stephen, R.A., F.N. Spiess, J.A. Collins, J.A. Hildebrand, J.A. Orcutt, K.R. Peal, F.L. Vernon, and F.B. Wooding. 2003. Ocean seismic network pilot experiment. Geochemistry, Geophysics, Geosystems 4, doi 10.1029/2002GC000485.

Stutzmann E., J.-P. Montagner, A. Sebai, W. Crawford, J.-L. Thirot, P. Tarits, D. Stakes, B. Romanowicz, J.F. Karczewski, J.-C. Koenig, J. Savary, D. Neuhauser, and S. Etchemendy. 2001. Moise: A prototype multi-parameter ocean bottom station. Bulletin of the Seismological Society of America 91:885-892.

Suetsugu, D., M. Shinohara, E. Araki, T. Kanazawa, K. Suyehiro, T. Yamada, K. Nakahigashi, H. Shiobara, H. Sugioka, K. Kawai, and Y. Fukao. 2005. Mantle discontinuity depths beneath the West Philippine Basin from receiver function analysis of deepsea borehole and seafloor broadband waveforms. Bulletin of the Seismological Society of America 95:1,947-1,956.

Sutherland, F.H., F.L. Vernon, J.A. Orcutt, J.A. Collins, and R.A. Stephen. 2004. Results from OSNPE: Improved teleseismic earthquake detection at the seafloor. Bulletin of the Seismological Society of America 94:1,868-1,878. 